headspace collections of S. bicolor, Z. mays, P. purpureum and $H$. tamba. Similarly, another EAD-active compound, 2-ethyl hexanol, has been reported as an electrophysiologically active component for male fruit piercing moth, Eudocima materna from fruit volatiles ${ }^{16}$. The attractiveness of bioactive compounds that elicited antennal response in the present study through GCEAD/EAG analyses needs to be further ascertained using detailed olfactometer bioassays. Although geranyl acetate was found to elicit maximum response from $C$. partellus males, it has been reported to reduce in male response by $34.6 \%$ Spodoptera littoralis. Linalool has been found to synergize the pheromone of Spodoptera exigua (Hubner), Helicoverpa zea (Boddie) and Cydia pomonella (Linnaeus), but not for Spodoptera litura (Fab.) ${ }^{17}$ and Spodoptera littoralis (Boisd.) ${ }^{18}$. Hence, before specifying the functional role of these volatiles in behaviour manipulation of $C$. partellus males and to using them for developing synergistic lures in combination with pheromone fractions, further laboratory studies involving olfactometer and wind-tunnel assays coupled with field evaluation are needed.

1. Sethuraman, V. and Narayanan, K., Biological activity of nucleopolyhedrovirus isolated from Chilo partellus (Swinhoe) (Lepidoptera: Pyralidae) in India. Asian J. Exp. Biol. Sci., 2010, 1, 325330

2. Nesbitt, B. F., Beevor, P. S., Hall, D. R., Lester, R., Davies, J. C. and Reddy, K. S., Components of the sex pheromone of the female spotted stalk borer, Chilo partellus (Swinhoe) (Lepidoptera: Pyralidae): identification and preliminary field trials. J. Chem. Ecol., 1979, 5(1), 153-163.

3. Sole, J., Sans, A., Riba, M. and Guerrero, A., Behavioural and electrophysiological responses of the European corn borer Ostrinia nubilalis to host-plant volatiles and related chemicals. Physiol. Entomol., 2010, 35(4), 354-363.

4. Reddy, G. V. P. and Guerrero, A., Interactions of insect pheromones and plant semiochemicals. Trends Plant Sci., 2004, 9, $253-$ 261.

5. Siddiqui, K. H., Sarup, P., Panwar, V. P. S. and Marwaha, K. K., Evolution of base ingredients to formulate artificial diets for the mass rearing of Chilo partellus (Swinhoe). J. Entomol. Res., 1977, 1, 117-131.

6. Tholl, D., Boland, W., Hansel, A., Loreto, F., Rose, U. S. and Schnitzler, J. P., Practical approaches to plant volatile analysis. Plant J., 2006, 45(4), 540-560.

7. Pagadala Damodaram, K. J., Gadad, H. S., Parepally, S. K., Vaddi, S., Ramanna Hunashikatti, L. and Bhat, R. M., Low moisture stress influences plant volatile emissions affecting herbivore interactions in tomato, Solanum lycopersicum. Ecol. Entomol., 2021, 46(3), 637-650.

8. Chamberlain, K., Khan, Z. R., Pickett, J. A., Toshova, T. and Wadhams, L. J., Diel periodicity in the production of green leaf volatiles by wild and cultivated host plants of stemborer moths, Chilo partellus and Busseola fusca. J. Chem. Ecol., 2006, 32(3), 565-577.

9. Birkett, M. A., Chamberlain, K., Khan, Z. R., Pickett, J. A., Toshova, T., Wadhams, L. J. and Woodcock, C. M., Electrophysiological responses of the lepidopterous stemborers Chilo partellus and Busseola fusca to volatiles from wild and cultivated host plants. J. Chem. Ecol., 2006, 32(11), 2475-2487.
10. Magara, H. J., Mutyambai, D. M., Charles, M. A., Otieno, S. A., Nyaga, T. M., Niassy, S. and Khan, Z. R., Responses of stem borer Chilo partellus to volatiles emitted by maize landraces exposed to signal grass (Brachiaria brizantha). J. Plant Interact., 2020, 15(1), 345-357.

11. Sen, A., Raina, R., Joseph, M. and Tungikar, V. B., Response of Trichogramma chilonis to infochemicals: an SEM and electrophysiological investigation. BioControl, 2005, 50(3), 429-447.

12. Bruce, T. J., Wadhams, L. J. and Woodcock, C. M., Insect host location: a volatile situation. Trends Plant Sci., 2005, 10(6), 269274.

13. Von Arx, M., Schmidt-Busser, D. and Guerin, P. M., Plant volatiles enhance behavioral responses of grapevine moth males, Lobesia botrana to sex pheromone. J. Chem. Ecol., 2011, 38(2), 222-225.

14. Landolt, P. J. and Phillips, T. W., Host plant influences on sex pheromone behavior of phytophagous insects. Аnпu. Rev. Entomol., 1997, 42, 371-391.

15. Knight, A. L., Hilton, R. and Light, D. M., Monitoring codling moth (Lepidoptera: Tortricidae) in apple with blends of ethyl (E, Z)-2,4-decadienoate and codlemone. Environ. Entomol., 2005, 34(3), 598-603.

16. Mallikarjun, K. R. M., Thippaiah, M., Raghavendra, A., Sharma, J. and Chakravarthy, A. K., Role of fruit volatiles and sex pheromone components in mate recognition in fruit piercing moth Eudocima materna Linnaeus (Lepidoptera: Erebidae). J. Entomol. Zool. Stud., 2019, 7(3), 1381-1387.

17. Fang, Y., Zeng, R., Lu, S., Dai, L. and Wan, X., The synergistic attractiveness effect of plant volatiles to sex pheromones in a moth. J. Asia Pac. Entomol., 2018, 21(1), 380-387.

18. Renou, M., Party, V., Rouyar, A. and Anton, S., Olfactory signal coding in an odor background. Biosystems, 2015, 136, 35-45.

Received 28 March 2021; revised accepted 30 June 2021

doi: $10.18520 / \mathrm{cs} / \mathrm{v} 121 / \mathrm{i} 4 / 578-581$

\section{Mites: an emerging problem for bumblebees in the Indian Himalayan Region}

\section{Rifat Husain Raina ${ }^{1, *}$, Babu Saddam ${ }^{1}$, Aejaz H. Parrey ${ }^{1,3}$, Purnima Pathak ${ }^{1}$ and Kailash Chandra ${ }^{2}$}

${ }^{1}$ Desert Regional Centre, Zoological Survey of India, New Pali Road, Jodhpur 342 005, India

${ }^{2}$ Zoological Survey of India, M-block, New Alipore 700 053, India ${ }^{3}$ Department of Zoology, School of Biosciences and Biotechnology, Baba Ghulam Shah Badshah University, Rajouri 185 234, India

To increase crop yield in the high altitude ecosystem in the Indian Himalayan Region (IHR), bumblebees are highly valued insects. An unwanted mites association with bumblebees is an example of a serious threat for the conservation of high-altitude agro-forestry

*For correspondence. (e-mail: raina.rifat@zsi.gov.in) 
ecosystem. Mites are emerging as a serious pest for bumblebees in the IHR and cause reduction in the pollinating efficiency of bumblebees, population health and in the spread of unwanted pathogens in nests. The mite Uropodina sp. (Acari: Mesostigmata) attacks on queens of Bombus simillimus, Bombus tunicatus and males of Bombus miniatus were recorded in the present study and fitness of bumblebees attacked by the mite population was also determined. $B$. simillimus queens were heavily attacked and wide distribution of Uropodina sp. on the body of the bumblebees was observed in this study.

Keywords: Bumblebees, crop yield, high-altitude ecosystem, mites, pollinators.

BUMBLEBEES belong to an insect order Hymenoptera: Apidae, which is the largest parasitic order. Several families in the order Hymenoptera are known for their deadly parasitic species which attack different insects and are also frequently used as biological control agents to maintain pest populations. Bumblebees are eusocial insects which live in colonies and serve as noteworthy pollinators for uncultivated and cultivated flowering plants as well as several crops in the high-altitude ecosystem, where survival and existence are difficult for other insects due to harsh environmental conditions.

Several studies have reported that different mites species from various parts of the world are endo- and exo-parasites of colonial and solitude bees ${ }^{1-3}$. The exterminatory pests of bees during bee-culture/keeping are recorded as Acarapis woodi and Varroa destructor which broadly influence the bee colonies and pollination performances at a large scale globally ${ }^{4-6}$. The rearing of bumblebees was initiated more than 20 years ago at a commercial level, while the mite-bumblebee relationship has come under focus only recently because of the importance of bumblebees in nature and their commercial demand ${ }^{7}$. Different kinds of pathogens and parasites have evolved and attained a higher proliferation during the rearing of bumblebee colonies above the ground level ${ }^{8,9}$. Velthuis and Van Doorn ${ }^{7}$ reported that some bumblebee colonies are imported in greenhouses of Europe from other countries and may help in the shipping of foreign pathogens, parasites and mites into Europe along with these colonies. During the last decade, protozoans have been widely studied as parasites, with a focus on the effect of the protozoans on the fitness of bumblebees ${ }^{10-13}$. In addition, mite attack in commercial bumblebees was recorded in Canada greenhouse bumblebee, Bombus occidentalis ${ }^{11}$ and European commercial colonies of Bombus terrestris ${ }^{14}$.

In this study we focus on the mite-bumblebee association in India, and mite effect on health of bumblebees. We particularly paid attention to study the fitness of bumblebees and to explore the mite-bumblebee relationship. We also studied the population of mites on particular individuals bumblebee and how these mites are associated with various parts of bumblebees. Several studies have been conducted on mite-bumblebee association and predators and parasites of bumblebees used for commercial purposes but less attention has been given to the natural enemies which are pests in the natural habitat. So a detailed study needs to be conducted in the natural habitat for pests of bumblebees.

Bumblebees were collected using swipe-net from Jammu and Kashmir and Himachal Pradesh, India (Figure 1). The collected specimens were transferred into killing jar containing ethyl acetate. The individual bumblebees with mite association were kept separately in vials $(75 \mathrm{ml})$ containing ethanol. The fitness and morphological disabilities of bumblebees due to mites were recorded simultaneously. Geological data were recorded using GPS (GARMIN GPS MAP 64SC) to indicate the location of the species (Figure 1). The specimens were brought to the laboratory at Desert Regional Centre, Zoological Survey of India, Jodhpur, Rajasthan, India for further studies and deposited in the National Zoological Collection. Mites were detached from the bumblebees during the sampling period and preserved in $90 \%$ alcohol for identification. A detailed study was done in the laboratory to examine the mites associated with various body parts of bumblebees, and how they affect the fitness of bumblebees. Photographs were taken with the help of a camera (Nikon Coolpix P1000 Digital Camera) and microscope (Nikon/SMZ25). Collected bumblebee specimens were identified in the laboratory up to species level with the help of the available literature (Table 1) and the detached mite samples were sent to Punjab Agricultural University, Ludhiana and Tamil Nadu Agricultural University, Coimbatore for identification.

Mite (Uropodina sp.) attack was only recorded in the queens of Bombus simillimus, Bombus tunicatus and male of Bombus miniatus (Figure $2 a-h$ ). No mites were found on other species of bumblebees in the present study, but the number of species attacked might increase in future based on sampling size in the Indian Himalayan Region (IHR). The tracheal mite in the Holarctic region has been reported to attack at least 25 bumblebee species $^{15-20}$. A detailed observation revealed that Uropodina sp. prefers to attack the queen because of her large size and adequate place for feed and reproduce.

Mites are widely studied pests in commercial honey bees and a little focus has been given to bumblebees ${ }^{15,19}$. A detailed examination of bumblebees attacked by Uropodina sp. shows that the mite heavily attacked on their body parts, particularly hind legs, mid legs, compound eyes, genitalia and abdominal air sacs (Figure $2 a-k$ ); only a small population was found on the dorsal side of the bumblebee body (Figure $2 h$ ). Heavy infestation of Uropodina sp. was found on the femur of hind legs of $B$. simillimus (Figure $2 c$ and $d$ ) compared to mid legs. $B$. simillimus queen was recorded as intentionally attacked by Uropodina sp. followed by $B$. tunicatus and B. miniatus 

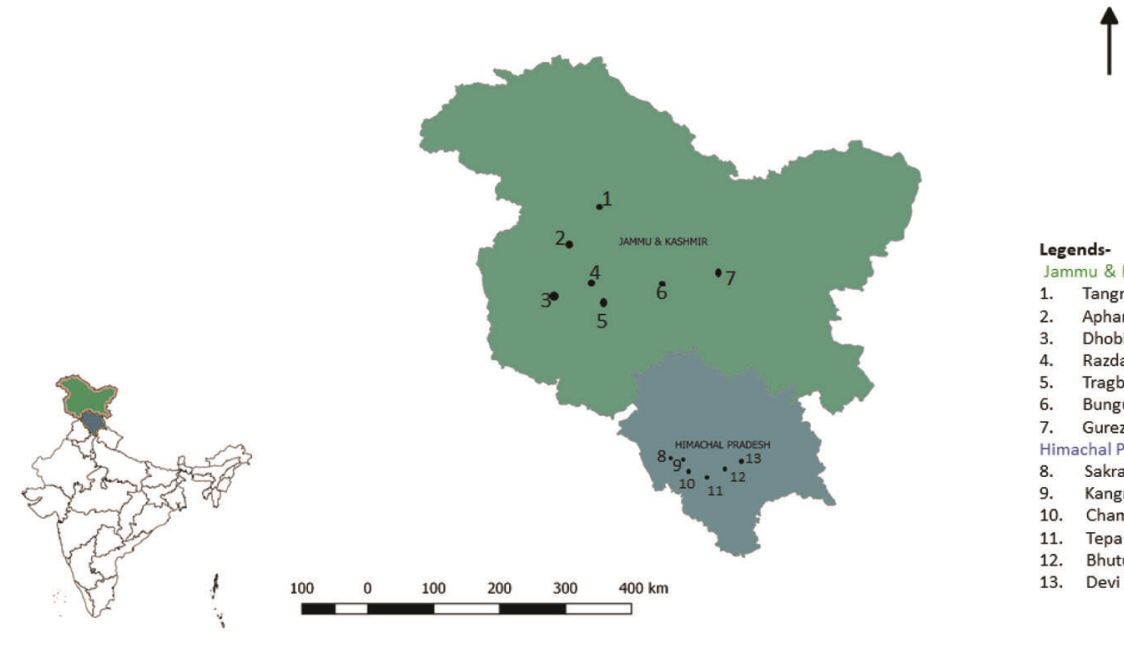

Figure 1. Sampling area.

Table 1. List of Bumblebee species attacked by Uropodina sp. in Indian Himalayan region

\begin{tabular}{llc}
\hline Species & \multicolumn{1}{c}{ District/locality/state } & Mites attack \\
\hline Bombus melanurus Lepeletier, 1835 & Bla/Tgm $(\mathrm{J} \& \mathrm{~K})$ & $\mathrm{N}$ \\
Bombus rufofasciatus Smith, 1852 & $\mathrm{Bla} / \mathrm{Tgm}(\mathrm{J} \& \mathrm{~K}), \mathrm{Cba} / \mathrm{Skn}(\mathrm{HP})$ & $\mathrm{N}$ \\
Bombus miniatus Bingham, 1897 & $\mathrm{Bla} / \mathrm{Awt}, \mathrm{Tbal}(\mathrm{J} \& \mathrm{~K})$ & $\mathrm{Y}$ \\
Bombus albopleuralis Friese, 1916 & $\mathrm{Bla} / \mathrm{Awt}(\mathrm{J} \& \mathrm{~K}), \mathrm{Kgr} / \mathrm{FV}(\mathrm{HP})$ & $\mathrm{N}$ \\
Bombus tunicatus Smith, 1852 & $\mathrm{Bla} / \mathrm{Dbgt}(\mathrm{J} \& \mathrm{~K}), \mathrm{Cba} / \mathrm{BN}(\mathrm{HP})$ & $\mathrm{Y}^{*}$ \\
Bombus ferganicus Radoszkowsi, 1893) & $\mathrm{Bla} / \mathrm{Dbgt}(\mathrm{J} \& \mathrm{~K})$ & $\mathrm{N}$ \\
Bombus simillimus Smith, 1852 & $\mathrm{Bndp} / \mathrm{RP}(\mathrm{J} \& \mathrm{~K}), \mathrm{Cba} / \mathrm{T}(\mathrm{HP})$ & $\mathrm{Y} *$ \\
Bombus keriensis Morawitz, 1886 & $\mathrm{Bndp} / \mathrm{RP}(\mathrm{J} \& \mathrm{~K}), \mathrm{Cba} / \mathrm{DK}(\mathrm{HP})$ & $\mathrm{N}$ \\
Bombus jacobsoni Skorikovi, 1912 & $\mathrm{Bndp} / \mathrm{Tbal}, \mathrm{Kpw} / \mathrm{BV}(\mathrm{J} \& \mathrm{~K})$ & $\mathrm{N}$ \\
Bombus asiaticus Morawitz, 1890 & $\mathrm{Bndp} / \mathrm{GV}(\mathrm{J} \& \mathrm{~K}), \mathrm{Cba} / \mathrm{T}(\mathrm{HP})$ & $\mathrm{N}$ \\
\hline
\end{tabular}

Y*, Heavy mite attack; Y, mite attack; N, No mite attack; Bla, Baramulla; Tgm, Tangmarg; Cba, Chamba; Skn, Sakrani; Awt, Apharwat; Kgr, Kangra; FV, Forest vatika; Dbgt, Dhobighat; BN, Bhotu Nala; Bndp, Bandipora; RP, Razdan Pass; T, Tepa; Tbal, Tragbal; DK, Devi Kothi; Kpw, Kupwara; BV, Bungus Valley; GV, Gurez valley; J\&K, Jammu \& Kashmir and HP, Himachal Pradesh.

respectively, because of their large size. Mites are endo and exo-parasites of bumblebees ${ }^{15}$, which feed and reproduce outside the body. However, in the present study we only recorded the exo-parasites. Mites affect the fecundity rate of bumblebees, leading to death. A heavy attack of Uropodina sp. on B. simillimus queen indicates that the mite individuals are dispersed everywhere on the body parts and affect the flight, reproduction, feeding and health of the queen.

B. simillimus, B. tunicatus and B. miniatus play a vital role in the conservation of wild flowers at high altitudes. They are distributed from the elevation range 1380$4180 \mathrm{~m}$ amsl in the IHR and serve nature by pollinating a wide range of wild flowers as well as high-altitude crops $^{21,22}$. B. simillimus pollinates several flowering plants found in the IHR, viz. Amaranthus caudatus, Hedera helix, H. nepalensis, Artemisia absinthium, Aster thomsonii, Carduus edelbergii, Carduus spp., Canturea iberica, Lavatera cashmeriana, Trifolium pratense, Trifolium repens, Rosa indica, Delphinium ajacis, Delphinium spp., Digitalis lanata, Lycopersium esculentum, Cirsium falcorneri, Cirsium spp., Cynara scolymus, Dahila variabilis, Tagetes patula, Taraxacum officinale, Impatients balsamina and Impatients glandulifera, Ipomea sp., Swertia petiolata, Althea rosea and Solanum nigrum. B. simillimus is considered as a potential pollinator for these flowering plants and therefore plays a pivotal role in their conservation.

B. tunicatus and B. miniatus also pollinate different varieties of flowering plants, viz. Allium cepa, C. edelbergii, Centaurea iberica, Cichorium intybus, Cirsium falconeri, Cirsium arvense, C. wallichii, C. scolymus, Helianthus annus, Scorzonera virgata, Tagetes patula, Tagetes spp., Zinnia elegans, Impatiens balsamina, I. edgeworthii, I. galdulifera, Campanula spp., Convolvulus arvensis, Dispsacus inermis, Gentiana sp., Hedera nepalensis, Aster himalicus, Antirrhinum majus, Artemisia absinthium, Artemisia spp., Swertia petiolata, Geranium sp., G. wallichianum, Nepata cataria, Prunella vulgaris, Stachys sericea, Lavatera cashmeriana, Astragalus sp., 

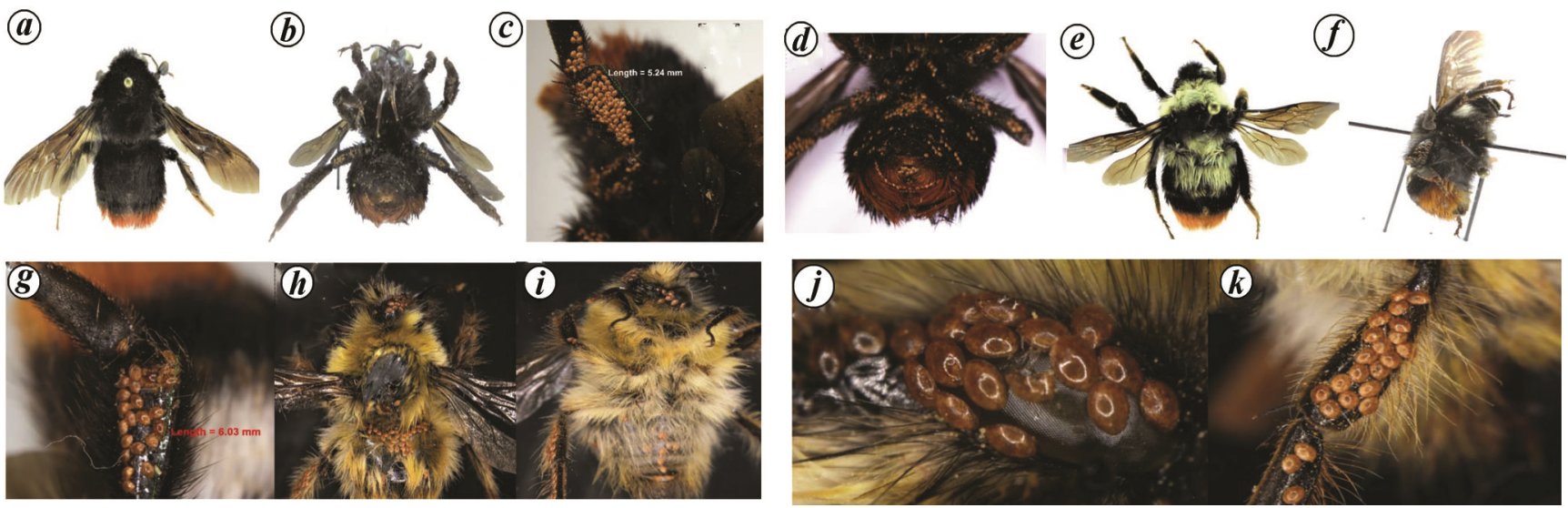

Figure 2. Mite (Uropodina sp.) attack on bumblebees. (a-d) Bombus simillimus Smith, 1852: (a) dorsal view, (b) ventral view, (c) Femur of hind leg and $(\boldsymbol{d})$ ventral view showing mites attack on female genitalia. $(\boldsymbol{e}-\boldsymbol{g})$ Bombus tunicatus Smith, 1852: (e) dorsal view, $(\boldsymbol{f})$ lateral view and $(\boldsymbol{g})$ femur of hind leg. (h-k) B. miniatus Bingham, 1897: (h) dorsal view, (i) ventral view, $(\boldsymbol{j})$ compound eye and $(\boldsymbol{k})$ femur of hind leg.

Indigofera heterantha, Lupinus polyphyllus, Robinia peusoacacia, Triflium pretense, Aconitium heterophyllum, Aconitium sp., Delpinium sp., Althea rosea, Potentilla atrosanguinea, Rosa webbiana, Digitalis lanata, D. purpurea, Pedicularis punctata and Pedicularis spp. ${ }^{21-24}$ in the $\mathrm{IHR}^{21,23,24}$. A mite-attacked bumblebee is not efficient like a normal bee as the IHR pollination potential may be reduced several fold after severe exploitation.

The transmission of disease-causing agents (bacteria, virus and protozoans) through mite association has been recorded in various countries, viz. The Netherlands, Japan, America, Indonesia and Europe in reared colonies of commercial bumblebees (B. terretris $)^{15}$. In the present study, we did not explore this aspect but there may be some cases of pathogen transmission through queens in bumblebee nests.

To the best of our knowledge, there are no previous studies of Uropodina sp. attack in B. simillimus, B. tunicatus and $B$. miniatus from the IHR. The mite attack affects the pollinating efficiency of bumblebees and cause the spreading of diseases in nests from one individuals to another. B. simillimus queen was found to be heavily attacked and less pollen grains were recorded from its body (Figure $2 a-d$ ) followed by $B$. tunicatus (Figure $2 e-g$ ) and B. miniatus (Figure $2 h-k$ ). In B. tunicatus and B. miniatus, Uropodina sp. was only recorded on the femur of hind and mid legs, and genital parts. However, Uropodina sp. was distributed on the whole ventral body parts of $B$. simillimus, including genital portion. B. miniatus compound eyes were mostly covered by Uropodina sp., which ultimately causes vision problems to find food and nest. Studies have revealed that commercial bumblebee populations affect the fauna by transferring pathogens and parasites $8,13,16,18,19$. The present study reveals that of Uropodina sp. attack on bumblebees can cause a wide range of problems in the IHR and can have an impact on high-altitude flora which are mainly conserved by these types of bees. The bumblebee species composition after mite attack can be reduced and this will ultimately affect pollination and crops yield in the IHR.

1. Eickwort, G. C., Evolution and life-history patterns of mites associated with bees. In Mites: Ecological and Evolutionary Analyses of Life-history Patterns (ed. Houck, M. A.), Chapman and Hall, New York, USA, 1994, pp. 218-251.

2. Klimov, P. B., OConnor, B. and Knowles, L. L., Museum specimens and phylogenies elucidate ecology's role in coevolutionary associations between mites and their bee hosts. Evolution, 2007, 61, 1368-1379.

3. Park, Y.-L., Kondo, V., White, J., West, T., McConnell, B. and McCutcheon, T., Nest-to-nest dispersal of Chaetodactylus krombeini (Acari, Chaetodactylidae) associated with Osmia cornifrons (Hym., Megachilidae). J. Appl. Entomol., 2009, 133, 174-180.

4. Sammataro, D., Gerson, U. and Needham, G. R., Parasitic mites of honey bees: life history, implications and impact. Annu. Rev. Entomol., 2000, 45, 517-546.

5. Baker, R. A., Hick, A. and Chmielewski, W., Aspects of the history and biogeography of the bee mites Tropilaelaps clareae and T. koenigerum. J. Apicult. Sci., 2005, 49, 13-19.

6. Baker, R. A., The parasitic mites of honeybees - past, present and future. J. Entomol. Res., 2010, 1, 1-7.

7. Velthuis, H. H. W. and Van Doorn, A., A century of advances in bumblebee domestication and the economic and environmental aspects of its commercialization for pollination. Apidologie, 2006, 37, 421-451.

8. Colla, S. R., Otterstatter, M. C., Gegear, R. J. and Thomson, J. D., Plight of the bumble bee: pathogen spillover from commercial to wild populations. Biol. Conserv., 2006, 129, 461-467.

9. Otterstatter, M. C. and Thomson, J. D., Does pathogen spillover from commercially reared bumble bees threatened wild pollinators? PLoS ONE, 2008, 3, e2771.

10. Imhoof, B. and Schmid-Hempel, P., Colony success of the bumble bee, Bombus terrestris, in relation to infections by two protozoan parasites, Crithidia bombi and Nosema bombi. Insect Soc., 1999, 46, 233-238.

11. Whittington, R. and Winston, M. L., Effects of Nosema bombi and its treatment fumagilin on bumbe bee (Bombus occidentalis) colonies. J. Invertebr. Pathol., 2003, 84, 54-58.

12. Rutrecht, S. T. and Brown, M. J. F., The life-history impact and implications of multiple parasites for bumble bee queens. Int. J. Parasito., 2007, 38, 799-808. 


\section{RESEARCH COMMUNICATIONS}

13. Otti, O. and Schmid-Hempel, P., A field experiment on the effect of Nosema bombi in colonies of the bumblebee Bombus terrestris. Ecol. Entomol., 2008, 33, 577-582.

14. Niwa, S., Iwano, H., Asada, S.-I., Matsumura, M. and Goka, K., A microsporidian pathogen isolated from a colony of the European bumblebee, Bombus terrestris, and infectivity on Japanese bumblebee. Jpn. J. Appl. Entomol. Zool., 2004, 48, 60-64.

15. Rozej, E., Witalinski, W., Szentgyorgyi, H., Wantuch, M., Moron, D. and Woyciechowski, M., Mites species inhabiting commercial bumblebee (Bombus territris) nests in Polish greenhouses. Exp. Appl. Acarol., 2012, 56, 271-282.

16. Yoneda, M., Furuta, H., Kanbe, Y., Tsuchida, K., Okabe, K. and Goka, K., Reproduction and transmission within a colony of bumblebee tracheal mite Locustacarus buchneri (Acari: Podapolipidae) in Bombus terrestris (Hymenoptera: Apidae). J. Appl. Entomol. Zool., 2008, 43, 391-395.

17. Yoneda, M., Furuta, H., Tsuchida, K., Okabe, K. and Goka, K., Commercial colonies of Bombus terrestris (Hymenoptera: Apidae) are reservoirs of the tracheal mite Locustacarus buchneri (Acari: Podapolipidae). J. Appl. Entomol. Zool., 2008, 43, 73-76.

18. Goka, K., Okabe, K. and Yoneda, M., Worldwide migration of parasitic mites as a result of bumblebee commercialization. $J$. Popul. Ecol., 2006, 48, 285-291.

19. Goka, K., Okabe, K., Yoneda, M. and Niwa, S., Bumblebee commercialization will cause worldwide migration of parasitic mites. J. Mol. Ecol., 2001, 10, 2095-2099.

20. Husband, R. W. and Husband, P. S., Studies of Locustacarus buchneri (Acari: Podapolipidae) tracheal parasites of grasshoppers and bumblebees. In Acarology IX Proceedings (eds Mitchell, R. et al.), 1997, pp. 335-338.

21. Saini, M. S., Raina, R. H. and Khan, Z. H., Food plants and stratification of Indian bumblebee (Apidae: Hymenoptera). Ann. Entomol., 2012, 30(1), 81-89.

22. Saini, M. S., Raina, R. H. and Khan, Z. H., A checklist of bumblebees (Hymenoptera: Apidae) from Indian Himalaya. J. Insect Sci., 2011, 24, 326-352.

23. https://bumblebeespecialistgroup.org/wp-content/uploads/2021/01/ BBSG-Annual-Report-2019.pdf (accessed on March 2020).

24. Williams, P. H., An annotated checklist of bumble bees with an analysis of patterns of description (Hymenoptera: Apidae, Bombini). Bull. Nat. Hist. Mus. (Entomol.), 1998, 67, 79-152 (updated at www.nhm.ac.uk/bombus/accessed 2015).

ACKNOWLEDGEMENTS. We thank the Director, Zoological Survey of India, Kolkata for providing the necessary facilities. National Mission on Himalayan Studies and the Ministry of Environment, Forests and Climate Change, Government of India for financial support. We also thank Dr Manmeet Brar Bhullar (Department of Entomology, Punjab Agriculture University, Ludhiana) and Dr K. Ramaraju (formerly Tamil Nadu Agricultural University, Coimbatore) for identifying the mite samples.

Received 26 March 2021; revised accepted 30 June 2021

doi: $10.18520 / \mathrm{cs} / \mathrm{v} 121 / \mathrm{i} 4 / 581-585$ 